\title{
RESILIENSI KOMUNITAS DAN KERAWANAN PANGAN DI PEDESAAN ACEH
}

\author{
Nulwita Maliati ${ }^{1}$, Ibrahim Chalid ${ }^{2}$ \\ ${ }^{1}$ Program Studi Sosiologi, Universitas Malikussaleh Lhokseumawe \\ Aceh-Indonesia \\ 2 Program Studi Antropologi, Universitas Malikussaleh Lhokseumawe \\ Aceh-Indonesia
}

Korespondensi: nulwita@unimal.ac.id

\begin{abstract}
Abstrak: Pasca bencana tsunami, masyarakat Aceh menghadapi situasi yang sulit dan permasalahan yang kompleks secara fisik dan sosial, terutama bagi rumah tangga di pedesaan yang memiliki keterbatasan aksesibilitas terhadap sumberdaya dan ketergantungan masyarakat yang tinggi terhadap sumberdaya alam. Penelitian tentang resiliensi komunitas masyarakat Aceh ini adalah upaya untuk mengkaji dimensi sosial-budaya sebagai dampak perubahan pasca konflik dan bencana tsunami. Hal itu penting diketahui karena ada banyak perubahan yang terjadi dalam kehidupan masyarakat Aceh akibat dampak tsunami terkait dengan kehidupan masyarakat di pedesaan yang tidak hanya menyangkut hubungan masyarakat dengan sumberdaya alam yang terganggu, tetapi juga penting diketahui lebih jauh tentang interaksi sesama anggota komunitas dan luar komunitas sehingga komunitas tetap bertahan walaupun selalu dihadapkan pada situasi yang rawan pangan. Oleh karena itu perlu upaya untuk menjelaskan bagaima resiliensi masyarakat pedesaan di Aceh pasca konflik dan bencana tsunami dalam kaitannya dengan kerawanan pangan. Analisis ini bermanfaat dalam upaya antisipasi dan mengatasi kerawanan pangan di masyarakat dengan sistem atau kelembagaan yang berbasis pada budaya lokal dan berorientasi pada pemecahan masalah kerawanan pangan.
\end{abstract}

Kata Kunci: Resilensi Komunitas, Aceh, Bencana 


\section{A. Pendahuluan}

Sosiologi adalah ilmu yang mempelajari tentang kehidupan bermasyarakat. Sosiologi lahir didasarkan pada fakta tentang adanya faktor-faktor yang bersifat struktural dan kultural. Sosiologi berkaitan dengan semua itu karena di dalam sosiologi gejala-gejala kultural dan struktural lainnya ditematisasikan, dianalisa dan dirumuskan secara sistematis. Oleh karena itu maka sifat dan isi sosiologi sangat mencerminkan sifat masyarakat di mana ilmu itu dipelajari (Laeyendecker, 1991).

Salah satu tokoh utama sosiologi adalah Emile Durkheim yang menyatakan bahwa studi sosiologi yang paling utama sekaligus mendasar adalah fakta sosial. Fakta sosial merupakan sebuah kekuatan dan struktur yang ada di luar, tetapi memiliki daya paksa terhadap individu. Sebagian kalangan memang masih mengakui pentingnya masyarakat namun mereka menganggap masyarakat adalah entitas tidak berbentuk sehingga sangat sulit untuk dipahami secara ilmiah. Durkheim berbeda pendapat tentang hal itu dan berkeyakinan bahwa masyarakat dapat diketahui secara ilmiah karena dibentuk oleh fakta sosial yang melampaui pemahaman individu. Karena itu masyarakat harus dilihat dengan cara observasi dan penelitian ilmiah (Arisandi, 2015).

Salah satu fakta sosial yang terjadi di muka bumi ini dan akan berlangsung terus sepanjang sejarah manusia adalah terjadinya bencana alam. Bencana alam merupakan fenomena alam yang memiliki keterkaitan sangat erat dengan fenomena sosial karena dampak terjadinya bencana alam sangat signifikan pada kondisi dan kelangsungan hidup manusia. Oleh karena itu kajian tentang bagaimana interaksi manusia terkait dengan bencana alam menjadi suatu fenomena yang dapat diteliti dengan menggunakan pemahaman tentang "fakta sosial”. Salah satu daerah yang menghadapi bencana besar di Indonesia ini adalah Aceh yang diguncang gempa bumi dan kemudian diterjang badai tsunami pada Tahun 2004. Dampaknya tidak hanya pada ekosistem yang ada tetapi juga berimplikasi luas pada kehidupan kehidupan masyarakat yang mengalami dampak bencana tersebut. Untuk memahami hal itu, maka diperlukan riset empiris sehingga dapat dipahami bagaimana fakta-fakta sosial tentang masyarakat Aceh secara struktural dan kultural dalam beradaptasi dengan resiko bencana. 


\section{B. Pembahasan}

\section{Aceh, Bencana dan Resiliensi Komunitas}

Emile Durkheim dipandang sebagai salah seorang yang meletakkan dasardasar sosiologi modern. Kita hidup di dalam masyarakat yang cenderung melihat segala sesuatu sebagai hal yang dapat dikaitkan dengan para individu, bahkan masalah-masalah yang jelas merupakan masalah sosial seperti rasisme, polusi dan resesi ekonomi. Durkheim berusaha mendekati berbagai hal dari perspektif yang menekankan dimensi sosial pada fenomena manusia. Bagi Durkheim, masyarakat terdiri dari "fakta-fakta sosial" yang melebihi pengertian intuitif kita dan harus diselidiki melalui pengamatan-pengamatan dan pengukuran-pengukuran. Faktafakta sosial didefinisikan Durkheim sebagai "cara-cara bertindak, berpikir dan merasa yang ada di luar individu dan memiliki daya paksa atas dirinya". Dalam hal ini, yang dimaksudkan adalah pengalaman umum manusia (Laeyendecker, 1991; Ritzer, 2014).

Untuk memisahkan sosiologi dari filsafat, Durkheim berargumen bahwa sosiologi harus diorientasikan kepada riset empiris. Namun sosiologi diancam oleh suatu aliran filosofis yang ada dalam sosiologi itu sendiri. Menurut Durkheim, dua tokoh utama sosiologi pada masa itu, Comte dan Herbert Spencer, jauh lebih tertarik berfilsafat, berteori abstrak, daripada mempelajari dunia sosial secara empiris. Comte dianggap mengandaikan secara teoritis bahwa dunia sosial sedang berevolusi di dalam arah menuju suatu masyarakat yang semakin sempurna, daripada melibatkan diri di dalam pekerjaan yang keras, teliti dan mendasar untuk mempelajari secara sungguh-sungguh hakikat yang sedang berubah dari beraneka masyarakat. Spencer dianggap mengandaikan begitu saja adanya harmoni di dalam masyarakat daripada mempelajari apakah harmoni itu benar-benar ada (Ritzer, 2014).

Mempelajari fakta-fakta sosial harus dilakukan dengan memperoleh data dari luar pikiran-pikiran kita sendiri dengan cara melakukan pengamatan dan eksperimentasi. Suatu fakta sosial adalah setiap cara bertindak, baku atau tidak, yang mampu menjalankan paksaan eksternal kepada seorang individu atau setiap cara bertindak yang umum pada suatu masyarakat yang independen dari 
perwujudan-perwujudan individualnya. Beberapa contoh fakta sosial adalah aturan-aturan hukum, kewajiban-kewajiban moral dan konvensi-konvensi. Kenyataan bahwa fakta sosial itu tetap ada, hanyalah dapat dijelaskan berdasarkan fungsi yang dimilikinya. Oleh karena itu, penjelasan sebab-akibat harus dilengkapi dengan penjelasan fungsional. "Fungsi suatu fakta sosial harus selalu ditemukan dalam hubungannya dengan tujuan sosial lainnya." Tujuan sosial itu, yang memberikan arti kepada fakta-fakta sosial, pada umumnya adalah mempertahankan masyarakat sebagai fakta sosial yang menyeluruh dan keselarasan umum di dalam masyarakat itu (Laeyendecker, 1991; Ritzer, 2014).

Durkheim membedakan fakta sosial menjadi dua, yaitu material dan nonmaterial. Fakta sosial material relatif lebih mudah dipahami karena bisa diobservasi secara langsung melalui indra, seperti gaya arsitektur, institusi keagamaan, bentuk teknologi, dan hokum serta perundang-undangan tertulis. Semua itu bisa dilihat secara langsung dan juga memiliki kekuatan memaksa kepada manusia. Sebagai contoh, ketika sudah menjadi undang-undang, hokum berada di luar individu serta memiliki kekuatan memaksa. Fakta sosial yang berikutnya bersifat nonmaterial. Fakta sosial jenis ini bersifat dorongan dari luar yang tidak tampak, seperti moral, norma, ajaran agama dan keyakinan, serta budaya. Jenis fakta sosial nonmaterial inilah yang menjadi focus dan inti sosiologi Emile Durkheim. Fakta sosial nonmaterial relatif sulit dikaji karena sifatnya yang tidak tampak dan abstrak. Namun, bukan berarti fakta tersebut tidak dapat diobservasi dan dijelaskan. Justru di sinilah sosiologi mempelajari fakta sosial nonmaterial yang tidak bisa diindra, tetapi memiliki daya paksa kuat serta bersifat dorongan eksternal. Ada empat bentuk fakta sosial nonmaterial, yaitu: moralitas, kesadaran kolektif, representasi kolektif dan arus sosial. Itulah empat fakta nonmaterial yang menjadi dasar dari sosiologi Durkheim. Fakta sosial nonmaterial menjadi tema kajian dari disiplin ilmu sosiologi yang membedakannya dengan bidang-bidang keilmuan lainnya, khususnya filsafat dan sosiologi. Fakta sosial harus melalui penyelidikan dan observasi yang memenuhi kaidah ilmiah (Arisandi, 2015).

Di dalam karya besarnya yang pertama, Durkheim membahas masalah pembagian kerja. Fungsi pembagian kerja adalah peningkatan solidaritas, karena 
individu-individu melakukan berbagai kegiatan, maka mereka menjadi tergantung satu sama lain dan karenanya terikat satu sama lain. Ketertiban, keselarasan, dan solidaritas merupakan keperluan-keperluan umum atau syarat-syarat hidup yang merupakan keharusan bagi organisasi sosial, maka hipotesa bahwa pembagian kerja adalah syarat hidup bagi masyarakat modern dapat dibenarkan. Agar pembagian kerja berfungsi sebagai kekuatan moral dan sosial di masyarakat modern, anomie, pembagian kerja yang dipaksakan, dan koordinasi spesialisasi yang tidak tepat harus diperhitungkan. Masyarakat-masyarakat modern tidak lagi dipersatukan oleh pengalaman-pengalaman dan kepercayaan bersama, tetapi justru melalui perbedaan-perbedaan mereka sendiri, selama perbedaan itu diizinkan berkembang dalam suatu cara yang mendorong interdependensi. Kunci bagi hal tersebut adalah keadilan sosial. Maka, tugas masyarakat yang paling maju adalah bagaimana mewujudkan keadilan. Sebagaimana ide mengenai masyarakatmasyarakat yang lebih rendah ialah menciptakan atau memelihara sekuat tenaga kehidupan bersama, maka cita-cita kita adalah membuat relasi-relasi sosial selalu lebih pantas, sehingga menjamin perkembangan bebas seluruh kekuatan masyarakat yang bermanfaat secara sosial (Laeyendecker, 1991; Ritzer, 2014).

Bencana alam merupakan fenomena alam yang selalu terjadi dalam sejarah kehidupan manusia. Cara menghadapinya merupakan kajian penting terutama dalam kaitannya dengan penggunaan sumberdaya dan adaptasi manusia terhadap lingkungannya. Secara global, 1,2 milyar orang (23\% dari populasi dunia) bertempat tinggal dalam jarak $100 \mathrm{~km}$ dari pantai dan kemungkinan $50 \%$ pada tahun 2030. Populasi itu sangat rentan terhadap bahaya-bahaya seperti banjir, tsunami, angin topan dan transmisi penyakit menular yang berhubungan dengan laut. Setiap tahun diperkirakan 10 juta orang mengalami banjir karena badai dan angin topan dan pada tahun 2080 diperkirakan 50 juta orang terancam resiko bencana alam akibat terjadinya perubahan iklim dan meningkatnya kepadatan penduduk. Untuk itu diperlukan kemampuan beradaptasi untuk mengatasi permasalahan akibat perubahan yang terjadi akibat bencana. Oleh karena itu perlu dieksplorasi keterkaitan antara ekosistem dan komunitas manusia sehingga dapat mengatasi kerawanan dan mendorong resiliensi (kelentingan) pasca bencana. Resiliensi yang tinggi dapat mendukung kapasitas sistem sosial-ekologi 
dalam menghadapi bencana sehingga dapat mempertahankan struktur-struktur yang penting, proses dan respon positif yang mendukung keberlanjutan komunitas. Resiliensi mencerminkan sejauh mana sistem bersifat adaptif berdasarkan kemampuan yang mereka miliki (dengan adanya keterbatasan organisasi dan tekanan faktor eksternal) serta sejauh mana sistem dapat membangun kapasitas untuk belajar dan terus beradaptasi (Adger, 2005).

Resiliensi komunitas dalam menghadapi bencana merupakan salah satu kajian yang dapat dilihat sebagai suatu fenomena tentang fakta sosial yang ada di masyarakat. Resiliensi berasal dari Bahasa Latin (resalire yang berarti bangkit kembali) telah menjadi istilah yang penting dalam bahasa dari berbagai disiplin mulai dari psikologi hingga ekologi. Definisi resiliensi yang utama adalah upaya meningkatkan kemampuan masyarakat untuk pulih setelah bencana secara eksplisit maupun implisit yang mengandung lima konsep inti berikut (Adger, 2013):

1. Attribute (ciri atau identitas) : resiliensi merupakan ciri atau identitas komunitas

2. Continuing (keberlanjutan) : resiliensi komunitas melekat dan dinamis sebagai bagian dari keberlanjutan masyarakat

3. Adaptation (kemampuan adaptasi) : komunitas mampu beradaptasi terhadap kesulitan

4. Trajectory (lintasan atau jalan) : adaptasi menunjukkan jalan yang berdampak positif bagi komunitas setelah krisis, terutama terkait fungsinya

5. Comparability (Komparatif) : identitas memungkinkan masyarakat untuk dibandingkan dalam hal kemampuan mereka untuk beradaptasi secara positif terhadap kesulitan

Adaptasi merupakan inti dari resiliensi. Adaptasi dapat terjadi baik dalam menanggapi atau dalam mengantisipasi krisis. Dalam berbagai kajian, resiliensi dianggap sebagai kekuatan dasar yang menjadi pondasi dari semua karakter positif dalam membangun kekuatan dalam proses adaptasi dengan lingkungannya. Secara umum, resiliensi ditandai oleh sejumlah karakteristik, yaitu: adanya kemampuan dalam menghadapi kesulitan, ketangguhan dalam menghadapi tekanan ataupun bangkit dari massalah. Resiliensi adalah sebuah proses dinamis 
yang mencakup adaptasi positif dalam konteks situasi yang sulit, dalam menghadapi bahaya maupun hambatan yang signifikan. Resiliensi mencakup keberadaan sejumlah kemampuan, karakteristik maupun berbagai kondisi yang tidak bertujuan untuk menghilangkan resiko, akan tetapi lebih pada upaya untuk mampu menghadapi hal-hal yang berpotensi memunculkan krisis dengan caracara yang positif. Bagi komunitas yang resilien, resiliensi membuat hidupnya menjadi lebih kuat. Artinya, resiliensi akan membuat komunitas berhasil menyesuaikan diri dalam berhadapan dengan kondisi-kondisi yang tidak menyenangkan, perkembangan sosial, budaya, kompetisi, bahkan dengan berbagai tekanan yang hebat. Setiap adaptasi idealnya dapat meningkatkan kapasitas masyarakat, yaitu, harus menghasilkan hasil dampak yang positif bagi masyarakat setelah mengalami kesulitan. Ini dapat dideteksi dengan mempertimbangkan tingkat fungsionalitas dari masyarakat setelah krisis. Berdasarkan hal itu, resiliensi komunitas adalah kemampuan untuk mengantisipasi risiko, membatasi dampak, dan bangkit kembali secara cepat melalui strategi bertahan hidup, adaptasi, evolusi, dan pertumbuhan dalam menghadapi gejolak perubahan serta memiliki kemampuan mengambil tindakan untuk keberlanjutan resiliensi mereka (Adger, 2013).

Di tingkat masyarakat, resiliensi terkait erat dengan keadaan ekonomi dan politik dari masyarakat, serta kekuatan lembaga-lembaga sosial dan jaringan sosial. Keberlanjutan adalah istilah yang terkait dengan resiliensi dan biasanya menjelaskan beberapa aspek terkait upaya mempertahankan sumber daya lingkungan dan kualitas hidup dari waktu ke waktu. Dalam konteks bencana, hal itu mengacu pada kemampuan lokal mentolerir dan mengatasi kerusakan, menurunnya produktivitas dan berkurangnya kualitas hidup yang ditimbulkan oleh peristiwa ekstrim tanpa bantuan dari luar yang signifikan. Bencana adalah sinyal dari kegagalan masyarakat untuk beradaptasi dengan lingkungannya. Resiliensi terhadap bencana menunjukkan kemampuan untuk keberlanjutan (Morrow, 2008).

Resiliensi didefinisikan sebagai kemampuan kelompok atau masyarakat untuk mengatasi tekanan eksternal dan gangguan sebagai akibat dari perubahan sosial, politik dan lingkungan. Definisi ini menyoroti ketahanan sosial dalam 
kaitannya dengan konsep ketahanan ekologi yang merupakan karakteristik ekosistem untuk mempertahankan diri dalam menghadapi gangguan. Ada hubungan yang jelas antara ketahanan sosial dan ekologi, terutama untuk kelompok sosial atau komunitas yang bergantung pada sumber daya ekologi dan lingkungan untuk mata pencaharian mereka. Tetapi tidak jelas apakah ekosistem yang tangguh memungkinkan masyarakat juga tangguh dalam situasi seperti itu. Resiliensi merupakan karakteristik yang berguna untuk menggambarkan situasi sosial dan ekonomi kelompok-kelompok sosial dan mengeksplorasi hubungan potensial antara ketahanan sosial dan ketahanan ekologi (Adger, 2013).

Menurut Adger (2005), resiliensi sosial dan ekologis terhadap bencana dan hasil dari setiap peristiwa ekstrim tertentu dipengaruhi oleh penumpukan atau erosi resiliensi baik sebelum dan sesudah bencana terjadi. Ketangguhan sistem sosial-ekologi menggabungkan mekanisme yang beragam untuk hidup dengan, dan belajar dari, perubahan dan guncangan tak terduga. manajemen bencana memerlukan sistem tata kelola multilevel yang dapat meningkatkan kapasitas untuk mengatasi ketidakpastian dan kejutan dengan memobilisasi berbagai sumber ketahanan. Dengan adanya resiliensi, berarti masyarakat memiliki kapasitas sistem sosial-ekologi untuk mengatasi gangguan berulang seperti badai atau banjir sehingga mampu untuk mempertahankan struktur penting dalam masyarakat. Resiliensi mencerminkan sejauh mana sistem adaptif komunitas mampu mengelola anggotanya komunitasnya dan sejauh mana sistem dapat membangun kapasitas untuk belajar dan beradaptasi. Bagian dari kapasitas ini terletak pada kemampuan regeneratif ekosistem dan kemampuan mereka dalam menghadapi perubahan yang penting untuk kehidupan manusia dan pembangunan masyarakat. Konsep resiliensi adalah pergeseran besar dalam perspektif tradisional, yang mencoba untuk mengontrol perubahan sistem yang diasumsikan stabil, untuk sudut pandang yang lebih realistis bertujuan mempertahankan dan meningkatkan kapasitas sistem sosial-ekologi untuk beradaptasi dengan ketidakpastian dan kejutan.

Dengan demikian, resiliensi komunitas adalah kemampuan untuk mengantisipasi resiko, membatasi dampak, dan bangkit kembali dengan cepat melalui strategi bertahan hidup, adaptasi, evolusi, dan pertumbuhan dalam 
menghadapi perubahan yang bergejolak. Definisi tersebut mengandung konsep inti sebagaimana telah diidentifikasi di atas, yaitu: resiliensi sebagai ciri atau identitas, dengan kemampuan beradaptasi pada intinya. Hal ini menunjukkan lintasan yang diinginkan, dan dapat memungkinkan masyarakat untuk menentukan seberapa tangguhnya mereka dan kemampuan melakukan tindakan untuk meningkatkan resiliensi mereka.

Salah satu dampak dari terjadinya bencana adalah rusaknya sumberdaya alam yang memiliki dampak sangat signifikan terhadap dinamika sistem perekonomian masyarakat, terutama di daerah pedesaan yang mayoritas penduduknya menggantungkan hidup pada pemanfaatan sumberdaya alam. Implikasi dari hal itu adalah terjadinya kerawanan pangan. Kerawanan pangandidefinisikan sebagai kondisi ketidakmampuan suatu rumah tangga/individu untuk menyediakan, mengakses dan memanfaatkan pangan dalam jumlah yang cukup pada kurun waktu tertentu, baik sebagai akibat dari kegagalan produksi, masalah daya beli dan nilai-nilai tentang pangan. Apabila hal itu terus berlanjut maka dapat berakibat pada terjadinya kelaparan, busung lapar atau gizi buruk. Secara teknis dari sisi waktu kejadiannya, kerawanan pangan dibagi menjadi 2 bagian yaitu : "Kerawanan Pangan Transien dan Kerawanan Pangan Kronis". Kerawanan Pangan Transien adalah : suatu keadaan rawan pangan yang bersifat mendadak dan sementara, yang disebabkan karena bencana, baik bencana alam (misalnya gempa bumi, tsunami, angin kencang, kekeringan) maupun yang disebabkan karena perbuatan manusia (misalnya banjir ataupun konflik sosial, dll). Kerawanan Pangan Kronis adalah : suatu kondisi ketidakmampuan rumah tangga untuk memenuhi standar minimum kebutuhan pangan anggotanya pada periode yang lama karena adanya keterbatasan kepemilikan lahan, aset produksi dan kekurangan pendapatan (Badan Ketahanan Pangan dan Penyuluhan Aceh, 2011).

Pada tanggal 26 Desember 2004, negara-negara di Asia Selatan dan Tenggara mengalami tsunami besar yang terkait dengan gempa kedua terbesar dalam catatan instrumental. Wilayah pesisir di wilayah Indonesia, Thailand, dan Malaysia yang letaknya dekat dengan pusat gempa dampak yang parah, berupa kerusakan sarana dan prasarana kehidupan dan juga kehilangan ratusan ribu 
nyawa. Aceh merupakan salah satu lokasi yang mengalami tragedi tsunami tahun 2004. Hal itu berakibat pada perubahan yang signifikan dalam berbagai aspek kehidupan mereka, terutama mereka yang tinggal di wilayah pesisir karena rusak dan terbengkalainya sumberdaya alam yang ada sehingga berdampak pada kondisi perekonomian masyarakat. Perubahan tersebut meliputi struktur sosialekonomi, rendahnya kemampuan masyarakat akibat lemahnya institusi lokal, keterbatasan aksesibilitas terhadap sumberdaya alam, perubahan kebijakan pemerintah, kurang efektifnya program penyuluhan pertanian, rendahnya nilai tukar produktivitas pertanian, dan lain-lain.

Menurut catatan pemerintah lokal di Aceh, selama adanya proyek dan intervensi kebijakan pasca konflik dan tsunami, situasi kerawanan pangan masih dapat dicegah. Pada masa awal pasca konflik dan tsunami di Aceh, terdapat banyak lembaga yang fokus terhadap isu kerawanan pangan, tetapi program-program yang dilaksanakan di masyarakat kurang efektif karena tidak adanya integrasi antar lembaga sehingga tidak berkelanjutan bahkan menciptakan ketergantungan dan permasalahan baru di pedesaan. Sejauh ini, masih sedikit penelitian yang berusaha memahami kondisi riil dan faktor penyebab terjadinya kerawanan pangan pada masyarakat pedesaan di Aceh secara lengkap sehingga belum dapat dilakukan identifikasi solusi yang terintegrasi.

Berdasarkan FSVA Nasional 2009, sebanyak 6 Kabupaten (Simeulue, Singkil, Aceh Jaya, Nagan Raya, Gayo Lues dan Aceh Utara) masuk dalam 100 kabupaten terentan yang menjadi prioritas. Sedangkan hasil FSVA Provinsi Aceh Tahun 2010, sebanyak 133 dari 251 kecamatan di Aceh (52,99\%) teridentifikasi rentan terhadap pangan. Secara Umum Kerentanan di Aceh terjadi disebabkan oleh : Kemiskinan, Akses Listrik, Akses Air Bersih, Underweihgt, dan perempuan buta huruf (Badan Ketahanan Pangan dan Penyuluhan Aceh, 2016).

Kerawanan pangan dapat diukur dari empat faktor utama, yaitu (Badan Ketahanan Pangan dan Penyuluhan Aceh, 2016):

1. Ketersediaan Pangan yang merupakan sejumlah kebutuhan pangan yang tersedia secara fisik dirumah tangga, baik yang berasal dari produksi sendiri, membeli di pasar maupun bantuan pangan. 
2. Aksesibilitas pangan yang dapat didefinisikan sebagai kemampuan rumah tangga dalam memperoleh sejumlah pangan yang dibutuhkan;

3. Pemanfaatan/Konsumsi pangan yang meliputi, pemanfaatan pangan oleh rumah tangga dan kemampuan individual dalam mengabsorsi nutrisi.

4. Kerentanan Pangan : berkaitan dengan kondisi sumberdaya alam pendukung di wilayah kajian.

\section{Penutup}

Pasca bencana tsunami, masyarakat Aceh menghadapi situasi yang sulit dan permasalahan yang kompleks secara fisik dan sosial, terutama bagi rumahtangga di pedesaan yang memiliki keterbatasan aksesibilitas terhadap sumberdaya dan ketergantungan masyarakat yang tinggi terhadap sumberdaya alam. Sebagaimana umumnya di Indonesia, masyarakat pedesaan di Aceh juga masih sangat tergantung pada sumberdaya alam dalam memenuhi kebutuhan hidup mereka. Rusaknya sumberdaya dan berbagai sarana serta prasarana pendukung kehidupan mereka berimplikasi pada terjadinya dinamika pada komunitas di pedesaan dalam menjalani kehidupan bermasyarakat, terutama dalam kehidupan perekonomian mereka agar dapat memenuhi kebutuhan keluarga, terutama kebutuhan pangan.

Pada dasarnya, masyarakat yang hidup di pedesaan memiliki mekanisme tersendiri dalam beradaptasi dengan lingkungannya dalam upaya untuk dapat tetap menjaga kelangsungan hidup dan komunitasnya. Demikian juga yang terjadi pada masyarakat di pedesaan Aceh pasca bencana tsunami Tahun 2004. Meskipun bencana itu menimbulkan dampak yang sangat signifikan terhadap kehidupan ekonomi masyarakat, namun ketahanan sosial-ekologi merupakan faktor penentu penting dalam melakukan reorganisasi dalam masyarakat setelah bencana. Individu dan masyarakat melakukan strategi adaptif yang melibatkan mobilisasi aset, jaringan, dan modal sosial baik untuk mengantisipasi dan bereaksi terhadap dampak bencana. Dengan demikian, walaupun kondisi sumberdaya alam sebagai sumber kehidupan masyarakat belum sepenuhnya normal pasca tsunami, namun tidak diperoleh informasi yang menunjukkan bahwa terjadi bencana kelaparan yang kronis pada masyarakat di yang mengalami dampak tsunami. 
Penelitian tentang resiliensi komunitas masyarakat Aceh ini adalah upaya untuk mengkaji dimensi sosial-budaya sebagai dampak perubahan pasca konflik dan bencana tsunami. Hal itu penting diketahui karena ada banyak perubahan yang terjadi dalam kehidupan masyarakat Aceh akibat dampak tsunami terkait dengan kehidupan masyarakat di pedesaan yang tidak hanya menyangkut hubungan masyarakat dengan sumberdaya alam yang terganggu, tetapi juga penting diketahui lebih jauh tentang interaksi sesama anggota komunitas dan luar komunitas sehingga komunitas tetap bertahan walaupun selalu dihadapkan pada situasi yang rawan pangan. Oleh karena itu perlu upaya untuk menjelaskan bagaima resiliensi masyarakat pedesaan di Aceh pasca konflik dan bencana tsunami dalam kaitannya dengan kerawanan pangan. Analisis ini bermanfaat dalam upaya antisipasi dan mengatasi kerawanan pangan di masyarakat dengan sistem atau kelembagaan yang berbasis pada budaya lokal dan berorientasi pada pemecahan masalah kerawanan pangan. 


\section{Daftar Pustaka}

Adger, W. Neil, et all. 2005. "Social-Ecological Resilience to Coastal Disasters. Science“12 Vol. 309, Issue 5737, pp. 1036-1039

Adger, W. Neil. 2013. Definitions of Community Resilience: An Analysis. A CARRI Report.

Arisandi, Herman. 2015. Buku Pintar Pemikiran Tokoh-tokoh Sosiologi Dari Klasik Sampai Modern. Penerbit IRCiSoD. Yogyakarta.

Badan Ketahanan Pangan dan Penyuluhan Aceh. 2011. Food Security and Vulnerability Atlas (FSVA). Banda Aceh.

Badan Ketahanan Pangan dan Penyuluhan Aceh. 2016. Neraca Bahan Makanan dan Peta Rawan Pangan serta Upaya Peningkatan Ketahanan Pangan. Makalah Workshop Dinas Kesehatan.

Laeyendecker, L. 1991. Tata, Perubahan dan Ketimpangan: Suatu Pengantar Sejarah Sosiologi. PT Gramedia Pustaka Utama. Jakarta.

Morrow, Betty Hearn. 2008. Community Resilience: A Social Justice Perspective. Community and Regional Resilience Initiative (CARRI) Report Research 4. Florida.

Ritzer, George. 2014. Teori Sosiologi: Dari Sosiologi Klasik Sampai Perkembangan Terakhir Postmodern. Pustaka Pelajar. Yogyakarta. 